\title{
EFEKTIVITAS PENERAPAN KONSEP DIVERSI TERHADAP ANAK YANG BERHADAPAN DENGAN HUKUM DALAM PERSPEKTIF SISTEM PERADILAN PIDANA
}

\author{
Mashendra \\ Program Studi Ilmu Hukum, Fakultas Hukum, \\ Universitas Muhammadiyah Buton, Jl. Betoambari No. 36 Baubau. \\ E-mail: hendraumi88@gmail.com
}

\begin{abstract}
Abstrak
Tujuan penelitian ini untuk mengetahui Efektivitas Penerapan Konsep Diversi terhadap Anak yang Berhadapan dengan Hukum dalam Perspektif Sistem Peradilan Pidana. Penelitian ini menggunakan dua jenis tipe penelitian, yaitu penelitian hukum normatif dan penelitian hukum empirik. Hasil penelitian menunjukan bahwa Pelaksanaan diversi didasari keinginan menghindari efek negetaif terhadap jiwa dan perkembangan anak oleh keterlibatannya dengan sistem peradilan pidana. Pelaksanaan diversi oleh aparat penegak hukum didasari oleh kewenangan aparat penegak hukum yang disebut discretion atau diskresi. Faktor-faktor yang menghambat penerapan diversi terkhusus di Kota Baubau adalah sebagai berikut: (1) Substansi Hukum. Diversi sudah diterapkan dalam beberapa bagian sistem hukum di Indonesia, namun terhambat oleh lemahnya implementasi dan penegakan hukum. Kelemahan yang terkandung dalam peraturan-peraturan yang terkait dengan penanganan $\mathrm{ABH}$; (2) Struktur Hukum. Kelemahan dari peraturan yang ada bisa teratasi apabila ada kepedulian dan sensivitas dari aparat penegak hukum dalam penanganan ABH. Hal ini terjadi karena mereka mempunyai diskresi untuk memberikan alternatif yang lebih baik daripada penjara untuk melindungi kepentingan masa depan anak; (3) Kultur Hukum/Partisipasi Masyarakat. Salah satu kendala terhambatnya penerapan diversi di Kota BauBau adalah paradigma masyarakat yang beranggapan bahwa setiap tindak kejahatan yang dilakukan ada balasannya (restributifjustice).
\end{abstract}

Kata kunci: diversi, pidana, anak.

\begin{abstract}
The purpose of this study was to determine the Effectiveness of the Application of the Concept of Diversion to Children Faced with Law in the Perspective of the Criminal Justice System. This study uses two types of research, namely normative legal research and empirical legal research. The results of the study show that the implementation of diversion is based on the desire to avoid negative effects on the soul and development of children by its involvement with the criminal justice system. The implementation of diversion by law enforcement officers is based on the authority of law enforcement officials called discretion or discretion. Factors that hinder the application of diversion especially in the City of Baubau are as follows: (1) Legal Substance. Diversion has been applied in several parts of the legal system in Indonesia, but is hampered by weak implementation and law enforcement. Weaknesses contained in the regulations relating to the handling of ABH; (2) Legal Structure. The weakness of the existing regulations can be overcome if there is concern and sensitivity from law enforcement officials in handling ABH. This happens because they have the discretion to provide a better alternative than prison to protect the future interests of the child; (3) Legal Culture / Community Participation. One of the obstacles to the implementation of diversion in the city of BauBau is the paradigm of the community who assume that every crime committed is reciprocated.
\end{abstract}

Keywords: diversion, criminal, child. 


\section{SANG PENCERAH}

Volume 3, Nomor 1, Februari 2017, ISSN 2460-5697, HIm. 60-78

Mashendra: Efektivitas Penerapan Konsep Diversi Terhadap ...

\section{Pendahuluan}

Fakta-fakta sosial yang belakangan ini terjadi dalam kehidupan masyarakat adalah permasalahan yang terkait dengan anak, dimana dalam kehidupan sosial yang sangat dipengaruhi oleh berbagai faktor tersebut kita dihadapkan lagi dengan permasalahan penanganan anak yang diduga melakukan tindak pidana. Anak merupakan tumpuan harapan masa depan masyarakat, bangsa, negara, ataupun keluarganya, oleh karena kondisinya sebagai anak, maka diperlukan perlakuan khusus agar dapat tumbuh dan berkembang secara wajar baik fisik dan rohaninya. Bertolak dari hal tersebut, pada hakikatnya pengaturan mengenai anak telah diatur secara tegas dalam konstitusi Indonesia yaitu berkaitan dengan pengaturan Hak Asasi Manusia yang diatur dalam Undang-Undang Negara Republik Indonesia Tahun 1945 Pasal 28B ayat (2) (Amandemen ke-2, 18 Agustus 2000) mengatur dengan jelas hak-hak anak yang salah satunya adalah berhak atas kelangsungan hidup. Tumbuh dan berkembang serta berhak atas perlindungan dari kekerasan dan diskriminasi.

Peraturan perundang-undangan yang telah dibuat oleh pemerintah Indonesia untuk memberikan perlindungan hak terhadap anak sebagai berikut: UndangUndang Dasar Negara Republik Indonesia Tahun 1945, Pasal 28B ayat (2); UndangUndang No. 4 Tahun 1979 tentang Kesejahteraan Anak, Pasal 2 ayat (3) dan ayat (4); Undang-Undang No. 39 Tahun 1999 Tentang Hak Asasi Manusia memuat 15 Pasal yaitu mulai dari pasal 52 s.d Pasal 66 yang secara khusus dinyatakan sebagai hak asasi anak. Pasal 52 ayat (1) dan (2); dan Undang-Undang No. 23 Tahun 2002.

Perlindungan anak merupakan pekerjaan penting yang harus terus dilakukan oleh seluruh unsur negara kita. Bentuk-bentuk perlindungan anak ini pun dilakukan dari segala aspek, mulai dari pembinaan pada keluarga, kontrol sosial terhadap pergaulan anak, dan penanganan yang tepat melalui peraturan-peraturan yang baik yang dibuat oleh sebuah negara.

Tindak pidana yang dilakukan anak merupakan masalah serius yang dihadapi setiap negara. Di Indonesia masalah tersebut banyak diangkat dalam bentuk seminar dan diskusi yang diadakan oleh lembagalembaga pemerintah dan lembaga terkait lainya. Kecenderungan meningkatnya pelanggaran yang dilakukan anak atau pelaku usia muda yang mengarah pada tindak kriminal, mendorong upaya melakukan penanggulangan dan penangananya, khusus dalam bidang hukum pidana (anak) beserta acaranya. Hal ini erat hubunganya dengan perlakuan khusus terhadap pelaku tindak pidana usia muda. Penyelesaian tindak pidana perlu ada perbedaan antara prilaku orang dewasa dengan pelaku anak, di lihat dari kedudukanya, seorang anak secara hukum belum dibebani kewajiban dibandingkan orang dewasa, selama seorang masih disebut anak, selama itu pula dirinya tidak dituntut pertanggungjawaban, bila timbul masalah terhadap anak diusahakan bagaimana haknya dilindungi hukum.

Polisi dalam sistem peradilan pidana adalah awal dari proses untuk memeriksa anak yang berhadapan dengan hukum. Polisi mempunyai suatu otoritas legal yang disebut diskresi, dimana dengan otoritas tersebut polisi berhak meneruskan atau tidak meneruskan suatu perkara. Kemungkinan polisi melakukan atau menggunakan otoritas diskresi ini sangat besar. Beberapa negara melalui otoritas diskresi, selalu melalui pemeriksaan awal polisi dapat menentukan bentuk pengalihan (diversi) terhadap suatu perkara anak. Berdasarkan deskripsi di atas, fokus penelitian ini adalah bagaimanakah Efektivitas Penerapan Konsep Diversi terhadap Anak yang Berhadapan dengan 


\section{SANG PENCERAH}

Volume 3, Nomor 1, Februari 2017, ISSN 2460-5697, HIm. 60-78

Mashendra: Efektivitas Penerapan Konsep Diversi Terhadap ...

Hukum dalam Perspektif Sistem Peradilan Pidana?

Tujuan penelitian ini adalah untuk mengetahui Efektivitas Penerapan Konsep Diversi terhadap Anak yang Berhadapan dengan Hukum dalam Perspektif Sistem Peradilan Pidana.

\section{Metode Penelitian}

\section{Jenis Penelitian}

Penelitian ini menggunakan dua jenis tipe penelitian, yaitu penelitian hukum normatif dan penelitian hukum empirik, karena mengkaji bahan pustaka atau sekunder sekaligus mencari data empiris dilapangan yang menyangkut permasalahan.

\section{Lokasi Penelitian}

Lokasi penelitian ini di Kota Baubau dengan fokus kepada Kepolisian Polres Baubau, Kejaksaan Negeri Baubau, Pengadilan Negeri Baubau, Serta Lembaga Pemasyarakatan Klas IIA Baubau.

\section{Populasi dan Sampel}

Populasi adalah seluruh objek, individu, gejala, kejadian dan unit yang diteliti. Di dalam penentuan sampel, penulis menggunakan metode purposive sampling, yaitu pengambilan sampel berdasarkan cirriciri tertentu. Kriteria yang diambil yaitu Kepolisian, PPA (Pusat Perlindungan Anak) sebanyak 4 (empat orang) sampel yang digunakan 2 (dua) Penyidik. Kejaksaan, 2 (dua) orang penuntut umum. Pengadilan Negeri 2 (dua) orang. Lembaga Pemasyarakatan 1 (satu) orang. Jadi populasi dan sampel dalam penelitian ini adalah populasi sebanyak 4 (empat) instansi dan sampel adalah 6 (enam) orang.

\section{Jenis dan Sumber Data}

Penelitian ini termasuk penelitian hukum normatif empiris, maka jenis data yang digunakan adalah data primer dan data sekunder. Sumber data yang digunakan dalam penelitian ini adalah:

1. Penelitian pustaka (library research) yaitu menelaah berbagai literatur yang ada hubungannya dengan obyek penelitian.

2. Peraturan perundang-undangan yang berlaku dalam hal ini Kitab UndangUndang Hukum Pidana (KUHP), Undang-Undang No. 3 Tahun 1997 tentang Pengadilan Anak serta UndangUndang No. 23 Tahun 2002 tentang Perlindungan Anak.

3. Penelitian lapangan (field research) yaitu pengumpulan data dengan mangamati secara sistematis terhadap fenomenafenomena beberapa kasus dalam berbagai media. Melakukan Observasi langsung ke lapangan khususnya Kepolisian Polres Baubau, Kejaksaan Negeri Baubau, Pengadilan Negeri Klas IIB Baubau. Serta Lembaga Pemasyarakatan Klas IIA Baubau.

\section{Teknik Pengumpulan Data}

Metode pengumpulan data yang digunakan dalam penelitian ini menyesuaikan dengan jenis data yang digunakan. Dalam memperoleh data sekunder dilakukan dengan cara penelitian kepustakaan (library research) dengan mengumpulkan bahan-bahan sekunder seperti peraturan perundang-undangan, buku, jurnal hukum, hasil penelitian dan sebagainya. Sedangkan data primer diperoleh dengan wawancara langsung dengan responden dan narasumber.

\section{Teknik Analisis Data}

Hasil yang diperoleh melalui studi kepustakaan dan juga wawancara secara langsung disusun secara sistematis dan analisis sesuai dengan metode pendekatan normatif empiris, maka pendekatan yang digunakan adalah analisis secara deskriptif kualitatif yaitu data yang bertitik tolak pada 
upaya dalam menemukan asas-asas dan teori-teori dalam menganalisis masalah dalam penelitian ini. Hal ini dimaksudkan agar penulis dapat menggambarkan keseluruhan hasil data yang diperoleh baik melalui wawancara maupun melalui studi kepustakaan. Selain itu penulis berharap dapat menggambarkan pendapat para ahli atau pakar hukum, maupun referensireferensi yang telah dikumpulkan. Dari semua hasil-hasil yang diperoleh oleh penulis diharapkan dapat dianalisis yang nantinya akan dihubungkan dengan rumusan peraturan perundang-undangan yang ada dan dapat diambil kesimpulan atau jawaban guna menjawab permasalahan yang diteliti.

\section{Pembahasan}

\section{Kriteria-Kriteria Tindak Pidana yang} Dapat Diselesaikan Melalui Diversi

\section{Pengelompokan Delikuensi Anak}

Dalam teori differential opportunity structure, Richard A. Cloward dan Loyd E. Ohlin mengelompokkan delinkuensi anak (Soekanto, dkk 1981:69)

Fenomena delinkuensi anak yang demikian hanya mengkhususkan bentukbentuk rumusan delik yang terbatas pada titel-titel kejahatan pencurian, pengelompokan, perampokan, dan penipuan. Pengelompokan dimaksud menunjukkan begitu sempitnya pemahaman delinkuensi anak yang tumbuh dan berkembang dalam realita-realita milenium ini. Bentuk kejahatan anak sudah semakin terstruktur dan pada nuansa kejahatan yang berkembang dan berteknologi dan menjurus pada kejahatan-kejahatan politik yang kausalistis. Delinkuensi anak yang demikian harus meletakkan subjek anak sebagai pelaku kejahatan anak sebagai subjek hukum yang dapat dipertanggungjawabkannya tindakantindakan perbuatan yang menimbulkan delinkuensi anak itu menjadi sah.

Delinkuensi anak terdapat dalam beberapa ketentuan perundang-undangan, seperti KUHPidana dan Undang-Undang No. 35 Tahun 2009 tentang Narkotika, yaitu:

a. Delikuensi dalam KUHP. Delinkuensi ini dapat digolongkan ke dalam 2 (dua) pengertian pokok KUHP. Ketentuan delinkuensi anak yang terdapat dalam KUHP menyeber pada beberapa pasal baik yang terdapat dalam delik kejahatan maupun pelanggaran, yaitu:

1) Delinkuensi anak dalam kejahatan terdiri dari: pencurian, perampokan, perkelahian, penggelapan, pembunuhan, pemerasan, poronografi, kejahatan kesusilaan, kejahatan yang mengganggu ketertiban umum, dan perkosaan.

2) Delinkuensi anak dalam pelanggaran, terdiri dari: pelanggaran lalu lintas, pelanggaran narkotika/narkoba, pelanggaran minuman keras, perkelahian, dan prostitusi.

b. Delinkuensi anak pada Undang-Undang No. 35 Tahun 2009 tentang Narkotika. Ketentuan delinkuensi anak, meliputi bagian khusus dari ketentuan di luar KUHP. Ketentuan mengenai delinkuensi anak hanya dirumuskan dari delik perbuatan yang diancam dan dilarang dalam penggunaan narkotika pada semua jenis dan tingkatan. Pasal 133 berbunyi:

1) Setiap orang yang menyuruh, memberi atau menjanjikan sesuatu, memberikan kesempatan, mengajurkan, memberikan kemudahan, memaksa dengan ancaman, memaksa dengan kekerasan, melakukan tipu muslihat, atau membujuk anak yang belum cukup umur untuk melakukan tindak pidana sebagaimana dimaksud dalam Pasal 111, Pasal 112, Pasal 113, Pasal 


\section{SANG PENCERAH}

Volume 3, Nomor 1, Februari 2017, ISSN 2460-5697, HIm. 60-78

Mashendra: Efektivitas Penerapan Konsep Diversi Terhadap ...

114, Pasal 115, Pasal 116, Pasal 117, Pasal 118, Pasal 119, Pasal 120, Pasal 121, Pasal 122, Pasal 123, Pasal 124, Pasal 125, Pasal 126, dan Pasal 129 dipidana dengan pidana mati atau pidana penjara seumur hidup, atau pidana penjara paling singkat 5 (lima) tahun dan paling lama 20 (dua puluh) tahun dan pidana denda paling sedikit Rp. 2.000.000.000,00 (dua miliar rupiah) dan paling banyak Rp. 20.000.000.000,00 (dua puluh miliar rupiah).

2) Setia orang yang menyuruh, memberi atau menjanjikan sesuatu, memberikan kesempatan, menganjurkan, memberikan kemudahan, memaksa dengan ancaman, memaksa dengan kekerasan, melakukan tipu muslihat, atau membujuk anak yang belum cukup umur untuk menggunakan narkotika, dipidana dengan pidana penjara paling singkat 5 (lima) tahun dan paling lama 15 (lima belas) tahun dan pidana denda paling sedikit Rp. 1.000.000.000,00 (satu milyar rupiah) dan paling banyak 10.000.000.000,00 (sepuluh milyar rupiah).

Pasal 134 berbunyi:

(1) Pecandu narkotika yang sudah cukup umur dan dengan sengaja tidak meloprkan diri sebagaimana dimaksud dalam Pasal 55 ayat (2) dipidana dengan pidana kurungan paling lama 6 (enam) bulan atau pidana denda paling banyak Rp. 2.000.000,00 (dua juta rupiah).

(2) Keluarga dari pecandu narkotika sebagaimana dimaksud pada ayat (1) yang dengan sengaja tidak melaporkan pecandu narkotika tersebut dipidana kurungan paling lama 3 (tiga) bulan atau pidana denda paling banyak $\mathrm{Rp}$. 1.000.000,00 (satu juta rupiah).

Ketentuan pidana yang dilarang terhadap anak adalah delinkuensi anak yang termuat dalam pasal-pasal sebagai berikut:

(1) Dilarang secara tanpa hak atau melawan hukum menanam, memelihara, memiliki, menyimpan, menguasai, atau menyediakan narkotika golongan I dalam bentuk tanaman. (Pasal 111)

(2) Dilarang secara tanpa hak atau melawan hukum memiliki, menyimpan, menguasai, atau menyediakan narkotika golongan I bukan tanaman. (Pasal 112)

(3) Dilarang secara tanpa hak atau melawan hukum memproduksi, mengimpor, mengekspor, atau menyalurkan narkotika golongan I. (Pasal 113)

(4) Dilarang secara tanpa hak atau melawan hukum menawarkan untuk dijual, menjual, membeli, menerima, menjadi perantara dalam jual beli, menukar, atau menyerahkan narkotika golongan I. (Pasal 114)

(5) Dilarang secara tanpa hak atau melawan hukum membawa, mengirim, mengangkut, atau mentransito narkotika golongan I. (Pasal 115)

(6) Dilarang secara tanpa hak atau melawan hukum menggunakan Narkotika Golongan I terhadap orang lain atau memberikan Narkotika Golongan I untuk digunakan orang lain. (Pasal 116)

(7) Dilarang secara tanpa hak atau melawan hukum memiliki, menyimpan, menguasai, atau menyediakan Narkotika Golongan II. (Pasal 117)

(8) Dilarang secara tanpa hak atau melawan huku memproduksi, 


\section{SANG PENCERAH}

Volume 3, Nomor 1, Februari 2017, ISSN 2460-5697, HIm. 60-78

Mashendra: Efektivitas Penerapan Konsep Diversi Terhadap ...

mengimpor, mengekspor, atau menyalurkan Narkotika Golongan II. (Pasal 118)

(9) Dilarang secara tanpa hak atau melawan hukum menawarkan untuk dijual, menjual, membeli, menerima, menjadi perantara dalam jual beli, menukar, atau menyerahkan Narkotika Golongan II. (Pasal 119)

(10) Dilarang secara tanpa hak atau melawan hukum membawa, mengirim, mengangkut, atau mentransito Narkotika Golongan II. (Pasal 120)

(11) Dilarang secara tanpa hak atau melawan hukum menggunakan Narkotika Golongan II terhadap orang lain atau memberikan Narkotika Golongan II untuk digunakan orang lain. (Pasal 121)

(12) Dilarang secara tanpa hak atau melawan hukum memiliki, menyimpan, menguasai, atau menyediakan Narkotika Golongan III. (Pasal 122)

(13) Dilarang secara tanpa hak atau melawan hukum meproduksi, mengimpor, mengekspor, atau menyalurkan Narkotika Golongan III. (Pasal 123)

(14) Dilarang secara tanpa hak atau melawan hukum menawarkan untuk dijual, menjual, membeli, menerima, menjadi perantara dalam jual beli, menukar, atau menyerahkan Narkotika Golongan III. (Pasal 124)

(15) Dilarang secara tanpa hak atau melawan hukum membawa, mengirim, mengangkut, atau mentransito Narkotika Golongan III. (Pasal 125)

(16) Dilarang secara tanpa hak atau melawan hukum menggunakan Narkotika Golongan III terhadap orang lain atau memberikan
Narkotika Golongan III untuk digunakan orang lain. (Pasal 126)

(17) Dilarang secara tanpa hak atau melawan hukum:

a. memiliki, menyimpan, menguasai, atau menyediakan Prekursor Narkotika untuk pembuatan Narkotika;

b. memproduksi, mengimpor, mengekspor, atau menyalurkan

Prekursor Narkotika untuk pembuatan Narkotika;

c. menawarkan untuk dijual, menjual, membeli, menerima, menjadi perantara dalam jual beli, menukar, atau menyerahkan Prekursor Narkotika untuk pembuatan Narkotika;

d. membawa, mengirim, mengangkut, atau mentransito Prekursor Narkotika untuk pembuatan Narkotika.

Dalam Pasal 128 Undang-Undang No. 35 Tahun 2009 tentang Narkotika disebutkan bahwa:

(1) Orang tua atau wali dari pecandu yang belum cukup umur, sebagaimana dimaksud dalam Pasal 55 ayat (1) yang sengaja tidak melapor, dipidana dengan pidana kurungan paling lama 6 (enam) bulan atau pidana denda paling banyak Rp. 1.000.000,00 (satu juta rupiah).

(2) Pecandu Narkotika yang belum cukup umur dan telah dilaporkan oleh orang tua atau walinya sebagaimana dimaksud dalam Pasal 55 ayat (1) tidak dituntut pidana.

(3) Pecandu Narkotika yang telah cukup umur sebagaimana dimaksud dalam Pasal 55 ayat (2) yang sedang menjalani rehabilitasi medis 2 (dua) kali masa perawatan dokter di 


\section{SANG PENCERAH}

Volume 3, Nomor 1, Februari 2017, ISSN 2460-5697, HIm. 60-78

Mashendra: Efektivitas Penerapan Konsep Diversi Terhadap ...

rumah sakit dan/atau lembaga rehabilitasi medis yang ditunjuk oleh pemerintah tidak dituntut pidana.

(4) Rumah sakit dan/atau lembaga rehabilitasi medis sebagaimana dimaksud pada ayat (3) harus memenuhi standar kesehatan yang ditetapkan oleh Menteri.

\section{Kriteria-kriteria Tindak Pidana yang Dapat Diselesaikan Melalui Diversi}

Adapun beberapa kriteria tindak pidana yang melibatkan anak sebagai pelaku yang harus diupayakan penyelesaiaannya dengan pendekatan diversi adalah:

a. Kategori tindak pidana yang diancam dengan sanksi pidana sampai dengan 1 (satu) tahun harus diprioritaskan untuk diterapkan diversi, tindak pidana yang diancam dengan sanksi pidana diatas 1 (satu) tahun sampai dengan 5 (lima) tahun dapat dipertimbangkan untuk melakukan diversi, semua kasus pencurian harus diupayakan penerapan diversi kecuali menyebabkan atau menimbulkan kerugian yang terkait dengan tubuh dan jiwa.

b. Memperhatikan usia pelaku, semakin muda usia pelaku, maka urgensi penerapan diversi semakin diperlukan.

c. Hasil penelitian BAPAS, bila ditemukan faktor pendorong anak terlibat dalam kasus pidana adalah faktor yang diluar kendali anak maka urgenitas penerapan diversi semakin diperlukan.

d. Kerugian yang ditimbulkan oleh tindak pidana anak, bila akibat yang ditimbulkan bersifat kebendaan dan tidak terkait dengan tubuh dan nyawa seseorang maka urgenitas penerapan diversi semakin diperlukan.

e. Tingkat keresahan masyarakat yang diakibatkan oleh perbuatan anak.

f. Persetujuan korban/keluarga korban.

g. Kesediaan pelaku dan keluarganya.

h. Dalam hal anak melakukan tindak pidana bersama-sama orang dewasa maka orang dewasa harus diproses hukum sesuai dengan prosedur biasa.

\section{Faktor-faktor yang Menghambat Terlaksananya Penerapan Diversi Terhadap Anak yang Berhadapan dengan Hukum}

Sistem hukum adalah suatu keseluruhan yang terdiri dari bagian-bagian atau sub-sub sistem hukum. Antar subsistem hukum yang satu dengan subsistem hukum yang lain saling ketergantungan dan tidak tumpang tindih.

Teori sistem hukum oleh Lawrence W. Friedman (dalam Ali: 2009:204) terdiri dari tiga komponen, yaitu substansi hukum, struktur hukum, dan kultur hukum.

Substansi, struktur, dan kultur hukum harus berjalan beriringan agar tercipta penegakan hukum yang adil dan bermanfaat untuk masyarakat. Apabila ketiga komponen ini tidak berjalan sebagaimana mestinya, maka akan menghambat tegaknya hukum di Indonesia. Hal ini juga akan menghambat penerapan diversi, yang diharapkan dapat menjadi solusi bagi anak yang berhadapan dengan hukum.

Menurut Syamsuddin (dalam Faisal: 2010:81), terdapat empat fakta yang menandai kondisi gagalnya proses hukum di Indonesia. Pertama, ketidakmandirian hukum. Kedua, integritas aparat penegak hukum yang buruk. Ketiga, kondisi masyarakat yang rapuh. Keempat, pertumbuhan hukum yang mandek. Masalah pokok penegakan hukum yang sebenarnya terletak pada faktor-faktor yang mempengaruhinya. Faktor-faktor tersebut mempunyai arti yang netral, sehingga dampak positif atau negatifnya terletak pada isi faktorfaktor tersebut. Faktor-faktor yang menghambat penerapan diversi terkhusus di Kota Baubau adalah sebagai berikut:

\section{Substansi Hukum}

Manusia di dalam pergaulan hidup, pada dasarnya mempunyai pandanganpandangan tertentu mengenai apa yang baik dan apa yang buruk. Penjabaran secara lebih 


\section{SANG PENCERAH}

Volume 3, Nomor 1, Februari 2017, ISSN 2460-5697, HIm. 60-78

Mashendra: Efektivitas Penerapan Konsep Diversi Terhadap ...

kongkrit terjadi di dalam bentuk kaidahkaidah. Dalam hal ini kaidah-kaidah hukum yang berisikan suruhan, larangan atau kebolehan. Kaidah-kaidah tersebut kemudian menjadi pedoman atau patokan bagi perilaku atau sikap tindak yang dianggap pantas atau yang seharusnya. Perilaku atau sikap tindak tersebut bertujuan untuk menciptakan, memelihara, dan mempertahankan kedamaian.

Substansi hukum menurut Lawrence M. Friedman (dalam Ali, 2009:204), mengemukakan bahwa substansi hukum adalah keseluruhan aturan hukum, norma hukum, dan asas hukum baik yang tertulis maupun yang tidak tertulis, termasuk putusan pengadilan.

Diversi sebenarnya sudah diterapkan dalam beberapa bagian sistem hukum di Indonesia, namun terhambat oleh lemahnya implementasi dan penegakan hukum. Salah satu bentuk penanganan terhadap anak yang rentan untuk terlibat atau dilibatkan dalam kenakalan atau suatu perbuatan melanggar hukum terhadap anak $(\mathrm{ABH})$ diatur dalam:

a. Pasal 16 ayat 3 UU No. 23 Tahun 2002 tentang Perlindungan Anak bahwa "penangkapan, penahanan, atau tindak pidana penjara anak hanya dapat dilakukan sebagai upaya terakhir".

b. Pasal 66 ayat 4 UU No. 39 Tahun 1999 tentang HAM bahwa penangkapan, penahanan, atau pidana penjara anak hanya boleh dilakukan sesuai dengan hukum yang berlaku dan hanya dapat dilaksanakan sebagai upaya terakhir.

c. Pasal 37 huruf b Konvensi Hak Anak bahwa tidak seorang anak pun akan dirampas kemerdekaannya, secara tidak sah atau sewenang-wenang. Penangkapan, penahanan, atau penghukuman seorang anak harus sesuai dengan hukum dan akan diterapkan sebagai upaya terakhir dan untuk jangka waktu yang paling pendek. d. Peraturan PBB untuk Perlindungan Anak yang dicabut kebebasannya (Havana Rules Pasal 17).

e. TR/1124/XI/2006 dari Kabareskrim POLRI tanggal 16 November 2006 dan TR/395/VI/2008 tanggal 9 Juni 2008 tentang Pelaksanaan Diversi dan Restorative Justice dalam Penanganan ABH. Peraturan Standar Minimum PBB untuk upaya-upaya non-penahanan (The Tokyo Rules).

f. Peraturan-peraturan minimum Standar PBB mengenai Administrasi Peradilan Bagi Anak (The Beijing Rules).

g. Peraturan Kepala Kepolisan Negara Nomor 8 Tahun 2009.

h. Petunjuk Teknis Jampidum Nomor: B532/E/I1/1995 Tanggal 9 November 1995 tentang Penuntutan Terhadap Anak di Bawah Umur.

i. Surat Keputusan Bersama Ketua MA-RI, Jaksa Agung RI, Kepala Kepolisian RI, Menteri Hukum dan HAM RI, Menteri Sosial RI, Menteri Pemberdayaan Perempuan dan Perlindungan Anak RI No. 166/KMA/SKB/XII/2009, No. 148A/A/JA.12/2009, No. B/45/XII/2009, No. M.HH-08 HM.03.02 Tahun 2009, No. 10/PRS-2/KPTS/2009, No. 02/Men. PP dan PA/XII/2009 tanggal 22 Desember 2009 tentang Penangkapan Anak yang Berhadapan dengan Hukum (Pasal 13 huruf a). "Penyidik melakukan upaya penanganan perkara anak yang berhadapan dengan hukum dengan pendekatan keadilan restorative untuk kepentingan terbaik bagi anak wajib melibatkan Balai Pemasyarakatan, orang tua, dan/atau keluarga korban dan pelaku tindak pidana serta tokoh masyarakat setempat".

Seperti yang telah dipaparkan di atas, sebagian pertauran yang berkaitan dengan penanganan $\mathrm{ABH}$ sebenarnya sudah berupaya menempatkan diversi, walaupun 


\section{SANG PENCERAH}

Volume 3, Nomor 1, Februari 2017, ISSN 2460-5697, HIm. 60-78

Mashendra: Efektivitas Penerapan Konsep Diversi Terhadap ...

belum secara komprehensif. Namum demikian, meskipun sudah ada berbagai perangkat hukum, dalam kenyataannya tidak cukup membawa perubahan yang cukup baik bagi anak-anak yang berhadapan dengan hukum. Namun dalam peraktiknya, unsur-unsur diversi itu tidak berjalan dengan baik karena beberapa kendala yang saling terkait satu sama lain sehingga menyulitkan upaya perlindungan hak anak.

Kelemahan yang terkandung dalam peraturan-peraturan yang terkait dengan penanganan $\mathrm{ABH}$ itu sendiri, yaitu UndangUndang Pengadilan Anak juga belum memberikan alternatif mekanisme penerapan diversi yang jelas untuk bisa menjadi pedoman bagi aparat penegak hukum. Menurut Ari Wahyu Irawan, S.H. (Hakim Anak Pengadilan Negeri BauBau, wawancara tanggal 6 Maret 2014) bahwa:

"Undang-Undang Pengadilan Anak sudah bagus, tetapi kelemahannya yaitu komposisinya yang menempatkan penjatuhan pidana lebih diatas daripada tindakan. Seharusnya penjatuhan tindakan lebih utama daripada penjatuhan pidana. Pidana penjara ditempatkan paling akhir."

Berkaitan dengan peraturan yang belum jelas tersebut, menurut Hernayati, S.H. (Jaksa Fungsional Kejaksaan Negeri BauBau, wawancara tanggal 7 Maret 2014) bahwa:

"Kami terbentur aturan jika ingin menghentikan penuntutan. Jadi harus ada aturan yang jelas".

Hal senada juga diungkapkan oleh Iswahyu Widodo (Hakim Anak di Pengadilan Negeri BauBau, wawancara tanggal 10 Maret 2014) bahwa:

"Jika ada tindak pidana ringan yang dilakukan oleh anak kemudian tidak ingin diproses secara hukum, undang-undangnya harus dirubah".
Tidak dapat disangkal bahwa tidak ada undang-undang yang sempurna atau lengkap. Pasti saja ada kekurangan atau kelemahannya. Secara umum dapat dikemukakan bahwa ada dua kelemahan pokok yang potensial terdapat dalam perundang-undangan. Pertama, dari segi perumusannya terkadang kurang lengkap, jelas dan kongkret. Kedua, dari aspek muatan materinya terkadang tidak relevan lagi dengan realitas sosial.

\section{Struktur Hukum}

Struktur hukum menurut Lawrence M. Friedman (Achmad Ali, 2009:204) mengemukakan bahwa struktur hukum adalah keseluruhan institusi-institusi hukum yang ada beserta aparatnya, mecakup antara lain kepolisian dengan para polisinya, kejaksaan dengan para jaksanya, pengadilan dengan para hakimnya, dan lain-lain.

Secara sosiologis, maka setiap penegak hukum tersebut mempunyai kedudukan dan peranan. Kedudukan merupakan posisi tertentu di dalam struktur kemasyarakatan. Kedudukan tersebut berisi tentang hak dan kewajiban tertentu. Hak dan kewajiban merupakan peranan. Oleh karena itu, seseorang yang mempunyai kedudukan tertentu dinamakan pemegang peranan. Suatu peranan tertentu dapat dijabarkan ke dalam unsur-unsur sebagai berikut:

1. Peranan ideal,

2. Peranan yang seharusnya.

3. Peranan yang dianggap oleh diri sendiri, dan

4. Peranan yang sebenarnya dilakukan.

Peranan yang ideal dan yang seharusnya berasal dari pihak lain, sedangkan peranan yang dianggap oleh diri sendiri dan peranan yang sebenarnya dilakukan berasal dari diri pribadi. Masalah peranan dianggap penting 


\section{SANG PENCERAH}

Volume 3, Nomor 1, Februari 2017, ISSN 2460-5697, HIm. 60-78

Mashendra: Efektivitas Penerapan Konsep Diversi Terhadap ...

karena pembahasan mengenai penegak hukum sebenarnya lebih banyak tertuju pada diskresi. Diskresi menyangkut pengambilan keputusan yang tidak sangat terikat oleh hukum, di mana penilaian pribadi juga memegang peranan.

Di dalam penegak hukum, diskresi sangat penting karena (1) Tidak ada perundang-undangan yang sedemikian lengkapnya sehingga dapat mengatur semua perilaku manusia; (2) Adanya kelambatan-kelambatan untuk menyesuaikan perundang-undangan dengan perkembangan-perkembangan di dalam masyarakat, sehingga menimbulkan ketidakpastian;

Kurangnya biaya untuk menerapkan perundang-undangan sebagaimana yang dikehendaki oleh pembentuk undangundang; dan (4) Adanya kasus-kasus individual yang memerlukan penanganan khusus.

Penggunaan perspektif peranan dianggap mempunyai keuntungankeuntungan tertentu karena (1) Fokus utamanya adalah dinamika masyarakat; (2) Lebih mudah untuk membuat suatu proyeksi karena memusatkan perhatian pada segi prosedural; (3) Lebih memperhatikan pelaksanaan hak dan kewajiban serta tanggung jawab.

Peranan yang seharusnya dari penegak hukum tertentu telah dirumuskan di dalam beberapa undangundang dan kebijakan-kebijakan dari institusi masing-masing. Sebenarnya kelemahan dari peraturan yang ada bisa teratasi apabila ada kepedulian dan sensivitas dari aparat penegak hukum dalam penanganan $\mathrm{ABH}$. Hal ini terjadi karena mereka mempunyai diskresi untuk memberikan alternatif yang lebih baik daripada penjara untuk melindungi kepentingan masa depan anak. Namun sayangnya, aparat penegak hukum lebih banyak yang mempunyai paradigm legalistik yang hanya berpedoman pada hukum tertulis an sich dengan alasan mereka memang dilatih untuk itu. Padahal, hukum sendiri juga memberikan kelenturan dalam penanganan $\mathrm{ABH}$.

Tidak semua aparat penegak hukum mempunyai paradigm legalistik, terbukti dengan banyaknya upaya damai yang dilakukan oleh Kepolisian Polres BauBau unit Perlindungan Anak dan putusan salah satu hakim di Pengadilan Negeri BauBau yang lebih banyak melakukan sanksi tindakan daripada sanksi pidana.

a) Kepolisian

Tugas dan kewenangan Kepolisian Negara Republik Indonesia dalam penanganan $\mathrm{ABH}$ sesuai dengan Pasal 8 Keputusan Bersama tentang Penanganan ABH meliputi:

1) Menyiapkan penyidik yang mempunyai minat, kemampuan, perhatian dan dedikasi dan bersertifikasi di bidang anak pada Mabes Polri dan jajaran kewilayahannya;

2) Meningkatkan jumlah Unit Pelayanan Perempuan dan Anak/ Unit PPA di Mabes Polri dan jajaran kewilayahannya;

3) Menyediakan ruang pemeriksaan khusus bagi anak di Mabes Polri dan jajaran kewilayahannya;

4) Melaksanakan pendidikan dan pelatihan tentang penanganan $\mathrm{ABH}$;

5) Menyusun panduan/pedoman standar tentang penanganan $\mathrm{ABH}$ dengan pendekatan keadilan restorative;

6) Membentuk kelompok kerja penanganan $\mathrm{ABH}$; dan

7) Melakukan sosialisasi internal, yang dalam pelaksanaannya dapat 


\section{SANG PENCERAH}

Volume 3, Nomor 1, Februari 2017, ISSN 2460-5697, HIm. 60-78

Mashendra: Efektivitas Penerapan Konsep Diversi Terhadap ...

bekerja sama dengan instansi terkait.

Berdasarkan Pasal 8 Keputusan Bersama di atas, maka pihak kepolisian mempunyai peranan yang besar terhadap penanganan $\mathrm{ABH}$ karena merupakan gerbang pertama dalam penegakan hukum.

Tabel 1 Data Penanganan ABH Tahun 2011-2012

\begin{tabular}{cccc}
\hline Tahun & $\begin{array}{c}\text { Jumlah } \\
\text { Kasus }\end{array}$ & $\begin{array}{c}\text { Upaya } \\
\text { Diversi }\end{array}$ & $\begin{array}{c}\text { Upaya } \\
\text { Hukum }\end{array}$ \\
\hline 2011 & 22 & 8 & 11 \\
2012 & 34 & 15 & 15 \\
\hline Total & $\mathbf{5 6}$ & $\mathbf{3 0}$ & $\mathbf{2 6}$ \\
\hline
\end{tabular}

Sumber: Polres Baubau Tahun 2013

Tabel 1 di atas menggambarkan bahwa penanganan $\mathrm{ABH}$ melalui pendekatan diversi dan diproses secara hukum formal terjadi keseimbangan di tahun 2011, sedangkan pada tahun 2012 penanganan $\mathrm{ABH}$ melalui cara diversi mengalami peningkatan dari 8 kasus menjadi 15 kasus.

Pihak kepolisian lebih mengutamakan upaya damai atau menggunakan cara diversi dalam menangani $\mathrm{ABH}$ daripada proses secara hukum karena lebih baik mengutamakan kepentingan terbaik untuk anak, tetapi tidak semua kasus ditangani secara diversi karena ada beberapa pertimbangan. Hal ini berdasarkan pendapat Aiptu Muslimin, S.H. (Kanit PPA di Polres BauBau, wawancara tanggal 13 Maret 2014), bahwa:

"Dalam Konvensi Hak Anak dan beberapa peraturan mengatur tentang $A B H$ bahwa penjara merupakan upaya paling akhir. Data di Polres BauBau banyak yang damai karena itulah yang diharapkan oleh undangundang dan kami mempunyai dasar hukum dan kami juga tidak mempunyai tahanan anak, kecuali anak itu putus sekolah dan melakukan tindak pidana sebagai mata pencarian atau dijadikan sebagai profesinya dan dilakukan secara berulang-ulang. Hal ini menjadi pertimbangan untuk anak yang ditahan. Jika terjadi kasus-kasus ringan seperti pencurian ringan, kami jarang melanjutkan ke proses hukum".

Hal senada juga diungkapkan oleh Wahyudi (Penyidik Anak Polres BauBau, wawancara tanggal 14 Maret 2014) bahwa:

"Penahanan anak dilakukan jika seorang anak melakukan kejahatan sebagai hobi dan dilakukan secara berulang-ulang, tetapi kalau kejahatan itu baru dilakukan, kita akan melakukan upaya damai".

Tabel 2 Sarana dan Prasarana Perangkat Hukum Penanganan ABH di Polres BauBau

\begin{tabular}{lclll}
\hline \multicolumn{1}{c}{$\begin{array}{c}\text { Proses Hukum } \\
\text { yang dilakukan }\end{array}$} & $\begin{array}{c}\text { Rnit } \\
\text { PPA }\end{array}$ & $\begin{array}{c}\text { Ruang } \\
\text { Tahanan } \\
\text { Khusus }\end{array}$ & Litmas & $\begin{array}{l}\text { Bantuan } \\
\text { Hukum }\end{array}$ \\
\hline 1. Keadilan & Ada & $\begin{array}{l}\text { Belum } \\
\text { Restoratif/Diversi }\end{array}$ & Ada & Ada \\
2. Proses Hukum & & & & \\
Formal & & & \\
Sumber: Polres BauBau Tahun 2013 &
\end{tabular}

Sumber: Polres BauBau Tahun 2013

Tabel 2 di atas menunjukkan bahwa pihak kepolisian di Polres Kota BauBau melakukan dua cara penanganan $\mathrm{ABH}$, yaitu dengan cara diversi dan proses hukum formal. Data ini juga menunjukkan bahwa tersedianya unit Perlindungun Perempuan dan Anak, Litmas dan Bantuan Hukum, tetapi tidak tersedianya tahanan khusus anak.

Kendala yang dihadapi di instansi kepolisian dalam melakukan pendekatan diversi adalah banyaknya para penegak hukum yang masih berparadigma legalistik, kaku, dan kurangnya pemahaman tentang penanganan $\mathrm{ABH}$. Hal ini diungkapkan oleh Aiptu Muslimin, S.H. (Kanit PPA, Polres Baubau wawancara tanggal 14 Maret 2014) bawah: 


\section{SANG PENCERAH}

Volume 3, Nomor 1, Februari 2017, ISSN 2460-5697, HIm. 60-78

Mashendra: Efektivitas Penerapan Konsep Diversi Terhadap ...

"Masih adanya kasus-kasus ringan yang diproses secara hukum oleh Kepolisian dikarenakan kurangnya pemahaman penyidik dan kurangnya sosialisasi terhadap aturan yang ada".

Hal senada juga diungkapkan oleh Hernayati, S.H. (Jaksa Fungsional Kejaksaan Negeri BauBau, wawancara tanggal 17 Maret 2014) bahwa:

"Seharusnya pada tingkat penyidikan dilakukan pendekatan keadilan restorative (diversi) agar tidak diteruskan pada tingkat penuntutan. Fakta yang terjadi, penyidik yang kadang menghalangi pihak pelaku dan korban untuk berdamai. Kita bukan ingin merendahkan penyidik, kenyataannya banyak penyidik yang tamatan SMA sehingga dalam memberikan pemahaman hukum kepada masyarakat sangat minim".

\section{b) Kejaksaan}

Kejaksaan merupakan lembaga pemerintah di bidang hukum yang memiliki tugas dan fungsi untuk melaksanakan kekuasaan negara khusus dalam wilayah penuntutan. Ketentuan tentang kedudukan kejaksaan ini diatur dalam Pasal 2 ayat 1 Undang-Undang No. 16 Tahun 2004 tentang Kejaksaan Republik Indonesia sebagai berikut:

1) Kejaksaan RI yang selanjutnya dalam undang-undang ini disebut kejaksaan adalah lembaga pemerintah yang melaksanakan kekuasaan negara di bidang penuntutan serta melaksanakan kewenangan lain berdasarkan undang-undang;

2) Kekuasaan negara sebagaimana dimaksud pada ayat 1 dilaksanakan secara merdeka;

3) Kejaksaan sebagaimana dimaksud pada ayat 1 adalah satu dan tidak terpisah-pisahkan.

Memperhatikan ketentuan tersebut, bekerjanya subsistem kejaksaan dalam kaitannya dengan peradilan pidana tidak terlepas dari bahan-bahan (BAP dan alat bukti) yang disampaikan oleh subsistem kepolisian. Sebelum melakukan penuntutan ke pengadilan, penuntut umum sebagai organ dari subsistem kejaksaan yang mendapat tugas menangani perkara pidana, terlebih dahulu melakukan pemeriksaan terhadap berkas perkara.

Di dalam kewenangan tersebut, tidak ditemukan pengaturan kewenangan bahwa Jaksa Penuntut Umum dapat melakukan tindakan lain, baik sebagai fasilitator dalam suatu negosiasi antara pelaku tindak pidana dengan korbannya, maupun sebagai mediator atas perkara tersebut.

Tugas dan kewenangan Kejaksaan Republik Indonesia dalam penanganan ABH sesuai dengan Pasal 7 Keputusan Bersama tentang penanganan $\mathrm{ABH}$, meliputi:

1) Melakukan penuntutan dengan memperhatikan kepentingan terbaik bagi $\mathrm{ABH}$;

2) Menyiapkan jaksa dan tenaga administrasi yang mempunyai minat, kemampuan, perhatian dan dedikasi serta bersertifikasi di bidang anak pada setiap kantor kejaksaan;

3) Menyediakan ruang pemeriksaan khusus bagi anak pada setiap kantor kejaksaan;

4) Mengadakan diskusi secara rutin serta pelatihan-pelatihan yang dibutuhkan;

5) Menyusun panduan/pedoman, surat edaran tentang penanganan $\mathrm{ABH}$ dengan pendekatan diversi;

6) Membentuk kelompok kerja penanganan $\mathrm{ABH}$;

7) Melakukan sosialisasi internal;

8) Mengefektifkan fungsi kepala kejaksaan tinggi dalam memberikan bimbingan dan pengawasan terhadap 


\section{SANG PENCERAH}

Volume 3, Nomor 1, Februari 2017, ISSN 2460-5697, HIm. 60-78

Mashendra: Efektivitas Penerapan Konsep Diversi Terhadap ...

jalannya penuntutan di daerah hukumnya.

Berdasarkan hasil penelitian, penulis menemukan adanya kesenjangan antara ketentuan yang telah diatur dalam Pasal 7 Keputusan Bersama tentang Penanganan $\mathrm{ABH}$ dengan kenyataan yang ada di lapangan. Kesenjangan itu dapat terlihat dari table di bawah ini:

Tabel 3 Data Penanganan ABH Kejaksaan Negeri Baubau Tahun 2011-2012

\begin{tabular}{cccc}
\hline Tahun & $\begin{array}{c}\text { Jumlah } \\
\text { Kasus }\end{array}$ & $\begin{array}{c}\text { Upaya } \\
\text { Diversi }\end{array}$ & $\begin{array}{c}\text { Uoaya } \\
\text { Hukum }\end{array}$ \\
\hline 2011 & 172 & - & 172 \\
2012 & 117 & - & 117 \\
\hline Total & $\mathbf{2 8 9}$ & - & $\mathbf{2 8 9}$ \\
\hline
\end{tabular}

Sumber: Kejaksaan Negeri Kota Baubau Tahun 2013

Tabel 3 menunjukkan bahwa tahun 2011 dan 2012 penanganan $\mathrm{ABH}$ di tingkat penuntutan tidak melalui pendekatan keadilan restorative (diversi), tetapi semua kasus anak diproses sesuai prosedur hukum formal. Menurut Hernayati, S.H. (Jaksa Fungsional Kejaksaan Negeri BauBau, wawancara tanggal 17 Maret 2014) bahwa:

"Kami dalam melakukan kebijakan, harus sesuai dengan aturan karena akan dilaporkan kepada pimpinan. Apabila sudah disetujui pimpinan, kemudian kami akan lanjutkan. Prosedur penghambat kami untuk melakukan pendekatan diversi karena kami harus melaksanakan tugas sesuai aturan yang berlaku".

Ali (dalam Faisal, 2010:62) memberikan kritikan terhadap penegak hukum positivist yang mengatakan:

"Dewasa ini cara berhukum bangsa ini snagat memprihatinkan, karena akibat penggunaan kacamata positivist yang kaku dalam menginterpretasikan berbagai undang-undang, maka berbagai kebijakan penegak hukum maupun putusan hakim gagal untuk menghasilkan suatu keadilan yang subtansial, melainkan hanya sekadar keadilan yang prosedural".

Pernyataan tersebut hendak mengatakan bahwa penerapan positivist hukum dalam praktik lebih mengutamakan prosedur atau hukum acara, maka tidak heran akan menghasilkan keadilan prosedural yang belum tentu merefleksikan keadilan yang substansial. Menurut Ary Wahyu Irawan, S.H. (Hakim Anak di Pengadilan Negeri BauBau, wawancara tanggal 18 Maret 2014) bahwa:

"Apabila kita memutus kasus anak berupa tindakan, yaitu dengan mengembalikan kepada orang tuanya. Pihak kejaksaan tetap melakukan upaya hukum apabila tidak sesuai dengan tuntutan mereka. Kendala yang kami hadapi adalah pihak kejaksaan belum menerima apabila anak dikembalikan ke orang tuanya, sehingga pihak kejaksaan melawan kami dengan upaya hukum".

Dalam hal ini, perlu cara pandang baru yang mampu menjelaskan problemproblem sosial secara utuh, sejalan dengan perkembangan keilmuan yang terjadi akhir abad ke-20. Dalam konteks hukum muncul teori chaos yang melihat hukum sebagai realitas yang bersifat cair. Menurut Charles Sampford, kaum positivist telah melakukan reduksi realitas. Oleh karena itu, teori hukum tidak harus berupa teori sistem mekanis, tetapi dapat berupa teori ketidakteraturan (disorder). Pada konteks tersendiri, pemikiran Charles Sampford tentang struktur hukum yang cair, telah menghantarkan Satjipto Rahardjo sampai pada anggapan tentang hukum yang disorder karena hukum dalam tatanan empirik sebagai tatanan yang tidak teratur.

Tabel 4 Sarana dan Prasarana Perangkat Hukum Penanganan ABH Di Kejaksaan Negeri BauBau

\begin{tabular}{ccccc} 
Proses & Jaksa & Ruang & Pertmbangan & Bantuan \\
Hukum & Anak & $\begin{array}{c}\text { Tahanan } \\
\text { yang }\end{array}$ & Hasil Litmas & Hukum \\
dilakukan & & Khusus & & \\
\hline
\end{tabular}




\section{SANG PENCERAH}

Volume 3, Nomor 1, Februari 2017, ISSN 2460-5697, HIm. 60-78

Mashendra: Efektivitas Penerapan Konsep Diversi Terhadap ...

\begin{tabular}{ccccc}
\hline Sidang & $\begin{array}{c}\text { Belum } \\
\text { ada }\end{array}$ & $\begin{array}{c}\text { Belum } \\
\text { ada }\end{array}$ & Ada & Ada \\
\hline Sumber: Kejaksaan Negeri & Kota & Baubau Tahun
\end{tabular}
2013

Tabel 4 di atas menunjukkan bahwa pihak kejaksaan di Kejaksaan Negeri Kota Baubau melakukan penanganan $\mathrm{ABH}$ dengan melalui proses hukum formal. Data ini juga menunjukkan bahwa tidak tersedianya jaksa yang bersertifikat jaksa anak dan belum ada ruang tahanan khusus anak. Jaksa selalu mempertimbangkan hasil Litmal dan tersedianya bantuan hukum untuk ABH. Menurut Ary Wahyu Irawan, S.H. (Hakim Anak di Pengadilan Negeri BauBau, wawancara tanggal 18 Maret 2014) bahwa:

"Kalau jaksa mempunya sertifikasi anak, jaksa tidak akan kaget ketika kami memutus tindakan untuk $A B H$ karena sesungguhnya nafas peradilan anak adalah tindakan".

Menurut Nurhayati (Kepala Seksi Bimbingan Klien Anak BAPAS Klas II BauBau, wawancara tanggal 19 Maret 2014) bahwa:

"Pengadilan anak sudah bagus, tetapi dalam penuntutan di kejaksaan, jika terjadi tindak pidana ringan akan dituntut beberapa tahun. Jadi yang perlu dititikberatkan untuk dibenahi adalah penyidik dan jaksa. Sebagus apapun penelitian yang kami lakukan, kalau jaksa memandang sebelah mata, penelitian kami tidak akan ada gunanya".

\section{c) Pengadilan}

Seperangkat peraturan menunjukkan bahwa peradilan sebagai subsistem peradilan pidana baik secara fungsional dan organisatoris mengalami perubahan yang cukup signifikan. Akan tetapi, secara fungsional lembaga peradilan berfungsi untuk memeriksa, mengadili dan memutus setiap perkara tindak pidana sesuai dengan ketentuan peraturan perundang-undangan yang masih berlaku. Adapun aktivitas maupun kerja dari lembaga peradilan dapat terlihat dari lembaga peradilan setelah adanya pelimpahan perkara ke pengadilan yang dilakukan oleh subsistem kejaksaan. Rangkaian kegiatan itu dilanjutkan dengan memeriksa dan diakhiri dengan putusan perkara pidana berdasarkan keyakinan hakim, serta juga berlandaskan pada asas bebas, jujur, dan tidak memihak. Dengan dijatuhkannya putusan kepada terdakwa berarti bekerjanya subsistem peradilan telah selesai secara fungsional.

Tugas dan kewenangan Mahkamah Agung Republik Indonesia dalam penanganan $\mathrm{ABH}$ sesuai dengan Pasal 6 Keputusan Bersama tentang penanganan ABH meliputi:

a. Menyiapkan hakim dan penitera yang mempunyai minat, kemampuan, perhatian, dan dedikasi yang bersertifikasi di bidang anak pada setiap pengadilan negeri;

2) Menyiapkan fasilitas dan prasarana, ruang tunggu dan ruang sidang yang ramah anak, serta ruang saksi anak pada setiap pengadilan secara bertahap;

3) Mengadakan diskusi secara rutin dan pelatihan-pelatihan yang dibutuhkan;

4) Menerbitkan Surat Edaran Mahkamah Agung/Peraturan MA/ dan menyusun standar operasional prosedur penanganan anak yang berhadapan dengan hukum dengan pendekatan keadilan restorative;

5) Membentuk kelompok kerja penanganan $\mathrm{ABH}$;

6) Melakukan sosialisasi internal;

7) Mengevektifkan fungsi ketua pengadilan dalam memberikan bimbingan dan pengawasan terhadap jalannya persidangan di dalam daerah hukumnya. 


\section{SANG PENCERAH}

Volume 3, Nomor 1, Februari 2017, ISSN 2460-5697, HIm. 60-78

Mashendra: Efektivitas Penerapan Konsep Diversi Terhadap ...

Berdasarkan hasil penelitian di lapangan, penulis melihat adanya kesenjangan antara tugas dan kewenangan yang diatur dalam Pasal 7 Keputusan Bersama dengan kenyataan yang ada di lapangan. Hal ini dapat terlihat dari table yang ada di bawah ini.

\begin{tabular}{ccccc} 
Tabel 5 & Sarana dan Prasana Perangkat Hukum \\
Penanganan ABH di & Pengadilan \\
Negeri Baubau & & & \\
\hline $\begin{array}{c}\text { Proses } \\
\text { Hukum } \\
\text { yang } \\
\text { dilakukan }\end{array}$ & $\begin{array}{c}\text { Jaksa } \\
\text { Anak }\end{array}$ & $\begin{array}{c}\text { Ruang } \\
\text { Tahanan } \\
\text { Khusus }\end{array}$ & $\begin{array}{c}\text { Pertmbangan } \\
\text { Hasil Litmas }\end{array}$ & $\begin{array}{c}\text { Bantuan } \\
\text { Hukum }\end{array}$ \\
\hline Sidang & $\begin{array}{c}\text { Belum } \\
\text { ada }\end{array}$ & $\begin{array}{c}\text { Belum } \\
\text { ada }\end{array}$ & Ada & Ada \\
\hline
\end{tabular}

Sumber: Pengadilan Negeri Kota Baubau Tahun 2013

Tabel 5 di atas menunjukkan bahwa penanganan $\mathrm{ABH}$ yang dilakukan oleh hakim anak di Pengadilan Negeri BauBau melalui proses persidangan yang dipimpin langsung oleh hakim yang mempunyai sertifikasi khusus menangani masalah anak. Akan tetapi, di Pengadilan Negeri BauBau belum tersedianya ruang tunggu, ruang sidang yang ramah anak, serta ruang saksi anak. Dalam memutuskan perkara anak, hakim sangat mempertimbangkan hasil Litmas, sehingga putusan yang dikeluarkan oleh hakim tidak hanya sanksi pidana, melainkan putusan berupa tindakan.

Tabel 6 Data Putusan Hakim terhadap ABH Tahun 2011-2012

\begin{tabular}{cccc}
\hline Tahun & $\begin{array}{c}\text { Jumlah } \\
\text { Kasus }\end{array}$ & $\begin{array}{c}\text { Sanksi } \\
\text { Pidana }\end{array}$ & $\begin{array}{c}\text { Sanksi } \\
\text { Tindakan }\end{array}$ \\
\hline 2011 & 162 & 160 & 2 \\
2012 & 205 & 172 & 21 \\
\hline Total & $\mathbf{3 7 5}$ & $\mathbf{3 3 2}$ & $\mathbf{2 3}$ \\
\hline $\begin{array}{l}\text { Sumber: } \\
\text { Tahun 2013 }\end{array}$ & & &
\end{tabular}

Tabel 6 di atas menggambarkan bahwa jumlah putusan hakim terhadap $\mathrm{ABH}$ di tahun 2011-2012 berupa sanksi pidana lebih besar daripada sanksi tindakan. Ini menandakan bahwa hakim dalam memutus perkara anak tidak mengutamakan kepentingan terbaik bagi anak, tetapi pada tahun 2012, sanksi berupa tindakan mengalami peningkatan yaitu dari 2 kasus menjadi 21 kasus. Ini menggambarkan bahwa tingkat pemahaman hakim tentang mengutamakan kepentingan terbaik bagi anak meningkat. Menurut Ari Wahyu Irawan (Hakim Anak di Pengadilan Negeri Baubau, wawancara tanggal 19 Maret 2014) bahwa:

"Selama saya bertugas di Pengadilan Negeri Baubau dari tahun 2011, saya lebih mengutamakan sanksi tindakan daripda sanksi pidana".

Hal serupa juga diungkapkan oleh Iswahyu Widodo (Hakim Anak di Pengadilan Negeri BauBau, wawancara tanggal 19 Maret 2014) bahwa:

"Pidana penjara merupakan ultimum remedium bagi siapapun. Kalau tidak dengan sangat terpaksa pedang bermata dua itu tidak digunakan, apalagi terhadap anak. Apabila anaknya masih bisa dibina, maka diputuskan untuk dikembalikan ke orang tua, tetapi kalau anak itu kenakalannya sudah berkali-kali, berarti kita putuskan untuk menyerahkan ke dinas sosial sebagai anak negara".

Jika undang-undang yang ada tidak mampu menangkap rasa keadilan masyarakat, hakim tidak boleh menjadi tawanan undang-undang dengan bertindak sebagai terompet undang-undang semata, tetapi hakim perlu secara kreatif melakukan terobosan hukum lewat penciptaan hukum melalui putusan-putusannya (judge made law). Meskipun dengan itu mengorbankan kepastian hukum yang merupakan salah satu asas yang fundamental dalam hukum pidana.

Penegakan hukum pada hakikatnya mengandung supremasi nilai substansial, 


\section{SANG PENCERAH}

Volume 3, Nomor 1, Februari 2017, ISSN 2460-5697, HIm. 60-78

Mashendra: Efektivitas Penerapan Konsep Diversi Terhadap ...

yaitu nilai keadilan. Seringkali publik memberikan komentar yang beragam mengenai penegakan hukum dan keadilan yang diasosiasikan dengan apa yang dihasilkan oleh lembaga peradilan sehingga peradilan merupakan simbolisasi dari upaya melahirkan penegakan hukum yang prokeadilan, sementara perhatian yang lebih penting terpusat pada peran aparatur penegak hukum yang mengoperasikan fungsi peradilan menjadi lebih kongkret.

Sisi lain dari proses penegakan hukum, dimana tidak asing bagi kita apa yang disebut dengan peradilan sesat, yaitu kegagalan proses mencari keadilan dalam seluruh aspeknya. Hal ini terjadi karena peradilan gagal memproses pelaku kejahatan secara tepat dan benar serta gagal menerapkan hukum dengan sebagaimana mestinya. Cikal bakal kegagalan peradilan ini sebagian besar dilakoni oleh perilaku aparat penegak hukum yang tidak mengabdi kepada nilai keadilan.

Aktualisasi dari kegagalan peradilan lembaga peradilan di era reformaasi menunjukkan suatu cara pandang dari aparat penegak hukum yang menjadikan hukum sebagai instrumen transaksional dalam memenuhi hasrat kepentingan kekuasaan, popularitas, bahkan sampai pada kepentingan bisnis semata.

Menurut Satjipto Rahardjo, Bismar Siregar termasuk tipe penegak hukum yang mengutamakan suara hati nuraninya daripada suara-suara yang lain. Hal ini tercermin dalam pernyataan Bismar Siregar yang mengatakan:

"Aku tidak menghindari caci, cercaan, dan celaan sesama. Sepanjang hati nuraniku berucap bahwa itulah yang adil dan tepat menjadi keputusan. Aku tidak mempertanggungjawabkan keputusan kepada sesama, tetapi yang utama kepada Tuhanku, hati nuraniku, baru kepada yang lain."

Pendapat di atas menunjukkan bahwa seorang penegak hukum harus memiliki kemampuan dan kemandirian untuk menggali nilai-nilai keadilan yang diterapkan dalam setiap putusan.

d) Balai Pemasyarakatan

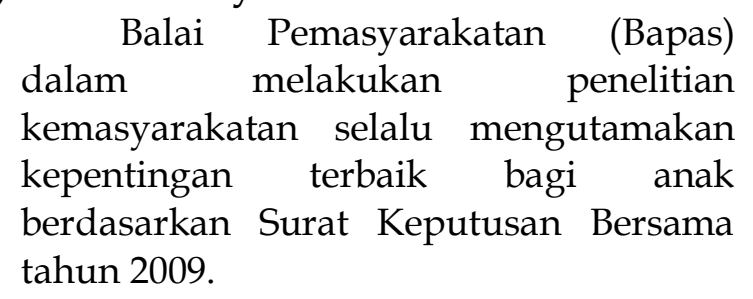

Tabel 7 Data ABH Berdasarkan Status Klien di Bapas Klas II Baubau

\begin{tabular}{cccc}
\hline Tahun & $\begin{array}{c}\text { Anak } \\
\text { Kembali } \\
\text { ke Orang } \\
\text { Tua/Wali }\end{array}$ & $\begin{array}{c}\text { Pidana } \\
\text { Bersyarat } \\
\text { Anak }\end{array}$ & $\begin{array}{c}\text { Lepas } \\
\text { Bersyarat } \\
\text { Anak }\end{array}$ \\
\hline 2011 & - & 2 & - \\
2012 & 7 & - & 3 \\
\hline Total & $\mathbf{7}$ & $\mathbf{2}$ & $\mathbf{3}$ \\
\hline
\end{tabular}

Sumber: BAPAS Klas II BauBau Tahun 2013

Tabel 7 menunjukkan bahwa pada tahun 2011 jumlah anak yang berstatus kembali ke orang tua/wali tidak ada, anak yang berstatus pidana bersyarat ada dua anak, dan anak yang berstatus lepas bersyarat tidak ada. Sedangkan pada tahun 2012 jumlah anak yang berstatus kembali ke orang tua/wali ada tujuh anak, pidana bersyarat tidak ada, dan lepas bersyarat 3 anak.

Tabel 8 Data Jenis dan Jumlah ABH di BAPAS Klas II BauBau

\begin{tabular}{lc}
\hline \multicolumn{1}{c}{ Jenis Tindak Pidana } & $\begin{array}{c}\text { Jumlah ABH } \\
\text { Tahun 2012 }\end{array}$ \\
\hline Pencurian & 175 \\
Penganiayaan & 64 \\
Laka Lantas & 21 \\
Narkoba & 10 \\
Senjata Tajam & 10 \\
Kekerasan/ancaman & 9 \\
kekerasa & \\
Pengrusakan & 7
\end{tabular}




\section{SANG PENCERAH}

Volume 3, Nomor 1, Februari 2017, ISSN 2460-5697, HIm. 60-78

Mashendra: Efektivitas Penerapan Konsep Diversi Terhadap ...

\begin{tabular}{lc} 
Pengeroyokan & 5 \\
Perbuatan cabul & 4 \\
Pembunuhan & 3 \\
Curas & 3 \\
Persetubuhan & 2 \\
Penghinaan & 1 \\
Percobaan pencurian & 1 \\
Penipuan & 1 \\
Lain-lain & 4 \\
\hline Jumlah & $\mathbf{3 2 0}$
\end{tabular}

Sumber: BAPAS Klas II BauBau Tahun 2012

Tabel di atas menggambarkan bahwa jumlah tindak pidana yang dilakukan anak sebanyak 320 kasus. Kasus tertinggi pertama adalah kasus pencurian sebanyak 175 kasus, diikuti oleh kasus penganiayaan sebanyak 64 kasus, dan tertinggi ketiga adalah kasus Laka Lantas sebanyak 21 kasus. Menurut Ari Wahyu Irawan, SH (Hakim Anak Pengadilan Negeri BauBau, wawancara tanggal 19 Maret 2014) bahwa:

"Perkara anak sebenarnya sangat kental untuk nuansa keadilan restoratif. Justru keadilan restoratif itu lahir dari petugas pembimbing kemasyaratan, tetapi hampir tidak pernah petugas BAPAS untuk merekomendasikan agar anak itu tidak dijatuhi pidana."

Berdasarkan wawancara yang dilakukan oleh penulis, pendapat Ari Wahyu Irawan, sangat bertentangan dengan Nurhayati, (Kasi BKA BAPAS Klas II BauBau, wawancara tanggal 20 Maret 2014), beliau mengatakan bahwa:

"Kalau kami lebih menitikberatkan pada pembinaan dan penjara merupakan upaya terakhir. Kami tidak pernah merekomendasikan untuk sanksi pidana."

BAPAS memiliki banyak kendala dalam menangani $\mathrm{ABH}$, diantaranya (a) Luas wilayah kerja yang sangat luas tidak seimbang dengan jumlah petugas BAPAS yang tersedia, tidak sebanding pula dengan biaya penelitian yang dianggarkan; dan (b) b. Kurangnya koordinasi diantara aparat penegak hukum dalam penanganan $\mathrm{ABH}$ yang berdasarkan kepentingan terbaik bagi anak.

\section{Kultur Hukum/Partisipasi Masyarakat}

Kultur hukum menurut Lawrence

M. Friedman (Achmad Ali, 2009:204) mengemukakan bahwa Kultur hukum adalah opini-opini, kepercayaankepercayaan (keyakinan-keyakinan), kebiasaan-kebiasaan, cara berpikir dan cara bertindak, baik dari para penegak hukum maupun dari warga masyarakat tentang hukum dan berbagai fenomena yang berkaitan dengan hukum.

Penegakan hukum berasal dari masyarakat dan bertujuan untuk mencapai kedamaian di dalam masyarakat, sehingga masyarakat dapat mempengaruhi penegakan hukum tersebut. Salah satu kendala terhambatnya penerapan diversi di Kota Baubau adalah paradigma masyarakat yang beranggapan bahwa setiap tindak kejahatan yang dilakukan ada balasannya (restributif justice). Sehingga jika ada anak yang melakukan perilaku menyimpang harus dilaporkan ke pihak kepolisian untuk dilanjutkan ke proses persidangan.

Kendala yang dihadapi oleh kepolisian dalam melakukan diversi adalah dari pihak korban yang tidak ingin memaafkan pihak pelaku karena adanya kerugian besar yang dialami pihak korban. Hal ini diungkapkan oleh Aiptu Muslimin, S.H. (Kanit PPA, wawancara tanggal 19 Maret 2014).

Paradigma negatif masyarakat terhadap penegak hukum juga mempunyai pengaruh besar terhadap penerapan diversi. Hal ini diungkapkan oleh Wahyudi (Penyidik Anak, wawancara tanggal 19 Maret 2014) bahwa: 


\section{SANG PENCERAH}

Volume 3, Nomor 1, Februari 2017, ISSN 2460-5697, HIm. 60-78

Mashendra: Efektivitas Penerapan Konsep Diversi Terhadap ...

"Ketika mereka didamaikan, masyarakat beranggapan bahwa penyidik membela dan dibayar oleh pihak pelaku sehingga pelaku tidak diproses. Padahal kami melakukan upaya damai untuk kepentingan terbaik bagi anak. Penyidik harus hati-hati dalam proses mediasi karena pihak korban beranggapan bahwa kami memihak ke pelaku."

Hal serupa juga diungkapkan oleh Hernayati, S.H. (Jaksa Fungsional Kejaksaan Negeri Baubau, wawancara tanggal 20 Maret 2014), bahwa:

"Penilaian negatif dari masyarakat jika mereka didamaikan atau membuat tuntutan ringan untuk pelaku adalah ada pihak yang tidak bertanggung jawab menganggap kami dibayar oleh pelaku atau kami dianggap punya hubungan keluarga dengan pelaku."

Menurut Ari Wahyu Irawan, S.H. (Hakim Anak di Pengadilan Negeri BauBau, wawancara tanggal 12 Maret 2014) bahwa:

"Pada umumnya, kendala untuk mendamaikan mereka adalah korban sudah mengalami kejadian seperti itu berkali-kali walaupun yang melakukan kejahatan itu bukan anak dan bukan orang yang sama. Kalau kasus perkelahian, orang tua korban bersikeras tidak menerima anaknya menjadi korban penganiayaan".

Tabel 9 Faktor Penyebab Digolongkan Jenis Tindak Pidana yang Dilakukan

\section{Jenis Tindak \\ Pidana Yang Dilakukan}

\begin{tabular}{ll}
\hline Pencurian & $\begin{array}{l}\text { 1. Tekanan ekonomi } \\
\text { 2. Pengaruh } \\
\text { orang/lingkungan }\end{array}$ \\
Penganiayaan & $\begin{array}{l}\text { 1.Ketidakstabilan emosi } \\
\text { 2.Pengaruh } \\
\text { orang/lingkungan }\end{array}$ \\
& $\begin{array}{l}\text { 1.Kealpaan } \\
\text { Laka Lantas }\end{array}$ \\
& $\begin{array}{l}\text { 2.Pengaruh } \\
\text { orang/lingkungan }\end{array}$ \\
Narkoba & 1.Tekanan ekonomi
\end{tabular}

2.Kealpaan

3.Pengaruh orang/lingkungan

Senjata tajam 1.Ketidakstabilan emosi

2.Pengaruh orang/lingkungan

Sumber: BAPAS Klas II BauBau Tahun 2013

Tabel 9 menunjukkan bahwa terjadinya tindak pidana yang dilakukan oleh anak disebabkan oleh adanya faktor tekanan ekonomi, pengaruh orang lain/lingkungan, ketidakstabilan emosi/emosional, dan kealpaan. Berdasarkan data tersebut, perlu adanya upaya serius dari pihak pemerintah untuk menciptakan lapangan kerja agar tingkat kejahatan yang dilakukan oleh anak mengalami penurunan. Di samping upaya oleh pemerintah, perlu adanya perhatian khusus dari orang tua agar meningkatkan pendidikan spiritual dan pengawasan terhadap perilaku anak agar anak lebih merasa diperhatikan oleh orang tuanya.

Di dalam peradilan restoratif, masyarakat terlibat sebagai mediator mengembangkan pelayanan masyarakat dan menyediakan kesempatan kerja sebagai wujud kewajiban, reparative, membantu korban dan dukung pemenuhan kewajiban pelaku. Dalam praktik mediasi, peran masyarakat dalam hal ini diwakili oleh tokoh masyarakat sebagai mediator dan sebagai wakil masyarakat yang mendandakan tidak ada dendam lagi dalam masyarakat. Masyarakat kini belum aktif dalam peran pelayanan untuk menyediakan kerja pelaku anak.

\section{Simpulan}

Simpulan penelitian ini bahwa pelaksanaan diversi didasari keinginan menghindari efek negetaif terhadap jiwa dan perkembangan anak oleh keterlibatannya dengan sistem peradilan pidana. Pelaksanaan diversi oleh aparat penegak 


\section{SANG PENCERAH}

Volume 3, Nomor 1, Februari 2017, ISSN 2460-5697, HIm. 60-78

Mashendra: Efektivitas Penerapan Konsep Diversi Terhadap ...

hukum didasari oleh kewenangan aparat penegak hukum yang disebut discretion atau diskresi. Faktor-faktor yang menghambat penerapan diversi terkhusus di Kota Baubau adalah sebagai berikut: (1) Substansi Hukum. Diversi sebenarnya sudah diterapkan dalam beberapa bagian sistem hukum di Indonesia, namun terhambat oleh lemahnya implementasi dan penegakan hukum. Kelemahan yang terkandung dalam peraturan-peraturan yang terkait dengan penanganan $\mathrm{ABH}$; (2) Struktur Hukum. Kelemahan dari peraturan yang ada bisa teratasi apabila ada kepedulian dan sensivitas dari aparat penegak hukum dalam penanganan $\mathrm{ABH}$. Hal ini terjadi karena mereka mempunyai diskresi untuk memberikan alternatif yang lebih baik daripada penjara untuk melindungi kepentingan masa depan anak; (3) Kultur Hukum/Partisipasi Masyarakat. Salah satu kendala terhambatnya penerapan diversi di Kota BauBau adalah paradigma masyarakat yang beranggapan bahwa setiap tindak kejahatan yang dilakukan ada balasannya (restributif justice). Sehingga jika ada anak yang melakukan perilaku menyimpang harus dilaporkan ke pihak kepolisian untuk dilanjutkan ke proses persidangan.

\section{Daftar Pustaka}

Amirudin, Zaenal Asikin. 2006. Pengantar Metode Penelitian Hukum. Jakarta: PT Raja Grafindo Persada.

Ali, Ahmad. 2009. Menguak Teori Hukum (Legal Theory) dan Teori Peradilan (Judisial Prudence). Jakarta: Kencana Prenada Media Grup.

Apong, Herlina. 2004. Perlindungan Terhadapa Anak yang Berhadapan Dengan Hukum. Jakarta: UNICEF.

Manan, Bagir. 2005. Sistem Peradilan Berwibawa. Yogyakarta: FH UII Press.
G.P. Hoefnagels, 1973. The Other Side of Criminology.

Herber L. Packer. 1967. The Other Side of Criminology. Holland: Kluwer Deventer.

Huda, Chairul. 2006. Dari Tiada Pidana Tanpa Kesalahan Menuju Kepada Tiada Pertanggungjawaban Pidana Tanpa Kesalahan. Jakarta: Kencana Prenada Media.

Jimly, Asshiddiqie, 1996. Pembaruan Hukum Pidana Indonesia (Studi Tentang BentukBentuk Pidana dalam Tradisi Hukum Fiqih dan Relevansinya Bagi Usaha Pembaruan KUHP Nasional). Bandung: Angkasa.

Kusuma, Mulyana W. 1981. Hukum dan Hak Asasi Manusia, Suatu Pemahaman Kritis. Bandung: Alumni.

1986. Hukum dan Hak-Hak Anak. Jakarta: CV Rajawali.

Marlina, 2010. Pengantar Konsep Diversi dan Restorative Justice dalam Hukum Pidana. USU Press, Medan.

Reksodiputo, Mardjano. 1997. Kriminologi dan Sistem Peradilan Pidana. Jakarta: Pusat Pelayanan dan Pengabdian Hukum UI, Jakarta.

Setyowati, Irma. 1990. Aspek Hukum Perlindungan Anak. Jakarta: Bumi Aksara.

Sunggono, Bambang. 2007. Metodologi Penelitian Hukum. Jakarta: PT Raja Grafindo Persada.

Wadong, Maulana Hasan. 2000. Pengantar Advokasi dan Hukum Perlindungan Anak. Jakarta: PT Gramedia Widiasarana Indonesia.

Waluyo, Bambang. 2000. Pidana dan Pemidanaan. Jakarta: Sinar Graha. 